\title{
Cleft as a Marker of A THETIC SENTENCE: EVIDENCE FROM IRISH AND RUSSIAN
}

\author{
MARIA SHKAPA
}

\section{Introduction}

Modern Irish is a strict VSO language, meaning that it does not allow for $\mathrm{SV}$ or OV inversion, the only phrases able to precede the verb being sentential adverbials ('yesterday', 'often' etc.).

Some pragmatic and grammatic functions that in other languages are served by inversion in Irish are performed by a biclausal (cleft) construction. As in English or French, it is used when focalisation of a constituent takes place (1). The construction also forms $w h$-questions (2).

(1)Dá bhféadainn an t-airgead a bhaint dé(sic) féin if I.could themoney PRT extract from.him self bheinn sásta, ach ní diot-sa is ceart I.would.be content but not from.you-CONT is(REL) right dom a chuid siúd a bhaint. to.me his share that PRT extract If I could get the money from him, I would be content, but it's not from you that it is right for me to get his money (MSF, 18-43).

(2) Cathain a tháinig tú?

when REL came you

When did you come? (Graiméar... 1999: 248)

Those two functions of the cleft are well-known and are described in standard Irish grammars. However, it is quite obvious that the cleft construction has other pragmatic meanings. Consider, for example, the following sentence starting a paragraph:

(3)Duine anoir ó Chill Mocheallóg a bhíodh sa man from.east from C.M. REL was in.the chathaoir (sic) againn i gcaitheamh na h-aimsiresin. town at.us during the time that A man from Cill Mocheallog in the east was in the town with us during that time (MSF, 24-6). ${ }^{1}$

\footnotetext{
${ }^{1}$ There is no presupposition that some foreign person lived in the town, so there is no subject focalisation here.
} 
The fact that the cleft in Celtic languages can have a non-focalising interpretation was mentioned as early as 1942 by Henry Lewis:

If we chanced in walking along a country road to meet straying cattle, and inquired the cause, we should as likely as not be told $y$ ffermwr adawodd y glwyd ar agor 'the farmer left the gate open'. We should be hearing an expression in a form that undoubtedly goes back to very early times. For the sentence does not mean 'it was the farmer that left the gate open'. There is no emphasis at all on the subject of the sentence. On the other hand, we might see a gate open which should have been shut, and it might be important to know who was the culprit. We should still be told $y$ ffermwr adawodd y glwyd ar agor, but this time $y$ ffermwr would be very differently stressed and intoned. The sentence would now mean in English 'it was the farmer that left the gate open' (Lewis 1942).

Thirty years later Proinsias Mac Cana in his paper on the Celtic word order noted that insular Celtic languages preserving VSO have a special construction where 'the emphasis expressed by the abnormal word-order (the same as cleft here $-M$. Sh.) applies to the whole verbal statement and not merely, or especially, to the subject or object which takes the initial position' (Mac Cana 1973: 102). He cites examples from Old, Middle and Modern Irish and Old and Modern Welsh, such as:

(4) 'Faoi Dhia, goidé tháinig ort?' ars an t-athair. by God what.it happened on.you said the father 'Micheál Rua a bhuail mé', ars an mac. M. R. REL hit me said the son 'In God's name, what happened to you?' asked the father. 'Micheál Rua gave me a beating', said the son. (Mac Cana 1973: 106)

(5) Lecc Tollcind. Unde nominatur. Ni handsa. Tollcend druth L. T. not difficult $T$. jester Echach meic Énnai Chendselaig ro marbad for Muir Icht ... of E. son of É. C. was.killed on Sea of Wight Lecc Tollcind. Whence is it named? It is not difficult: Tollcend the jester of Echu mac Énna was slain in the Sea of Wight. (Mac Cana 1973: 106)

The topic did not receive further investigation until the notion of theticity was developed in linguistics.

Since Kuroda's work on Japanese (Kuroda 1972), a discourse situation like that described by Henry Lewis and Proinsias Mac Cana is usually labeled 'thetic' (less common names being 'sentence focus 
utterance' and 'neutral description'). The term 'thetic' goes back to the philosophy of language and Vilem Mathesius' work on functional sentence perspective (Mathesius 1929). In opposition to categorial sentences that have both topic and comment, both presupposition and assertion, thetic sentences were said to be all-comment and all-assertive.

However, no universal definition of theticity has been worked out so far due to the fact that pragmatic categories involved, such as 'topiccomment', 'assertion-presupposition', have neither similar nor straightforward manifestation in languages (Sasse 1995: 7). As H. J. Sasse points out, it would be more efficient to study single cases that are acknowledged to be thetic and 'try to abstract a common core which can serve as a basis for generalization' (Sasse 1995: 3). As a working definition, we can take his statement that a thetic sentence is a sentence that 'expresses a pragmatically unanalysed state of affairs' and presents a whole situation at once, while a categorial sentence 'selects one of the participants of the state of affairs to present it as a predication base and arranges the rest in such a way that it forms the predication about the selected predication base' (Sasse 1987: 558).

Thetic/categorial distinction may have various manifestations:

I. Intonation

English

CATEGORIAL

THETIC

(6) How's your neck?

(7) What's the matter?

My neck HURTS. My NECK hurts. (Sasse 1995: 4)

II. Word order

Italian

CATEGORIAL

THETIC

(8) Il collo mi fa male

(9) Mi fa male il coll (Sasse 1995: 8)

III. Binar construction containing a relative clause, e.g. cleft construction

French

CATEGORIAL

(10) Mon cou il me fait mal

THETIC

(Sasse 1995: 8)

(11) J'ai le cou qui me fait mal

(12) Mon prof il arrive

(Lambrecht 2000: 509)

(13) Voilá mon prof qui arrive

Other less common means mentioned in literature are nominalisation and incorporation (see Sasse 1985). Usually more then one device for coding theticity is present in a given language. These devices may work together, 
e.g. intonation + word order change, be interchangeable, or in complementary distribution (see Lambrecht, Polinsky 1997, Lambrecht 2001, Sasse 1985 for details).

In Irish, besides prosodic means which will not be discussed here, theticity can be marked in the following ways:

I. Various non-finite constructions, e.g. verbal noun clause

Cad chuige? - Dónall a bheith $i$ ngrá.

why D. REL be:VN in love

Why so? - Donald is in love. (Graiméar... 1991: 234)

\section{Cleft construction}

(15) Is do dhaoine le cumas bunúsach sa Ghaeilge atá is forpeople with capability basic in.the Irish REL.is an Fáinne Airgid.

the Ring of.silver

The silver ring is for people with basic knowledge of Irish (http://www.gaelport.com) ${ }^{2}$

III. Making a sentence 'artificially categorial' by means of topicalisation of a constituent that is focal in discourse

(16) An t-ealaíontóir gur mhóraici an damhanalla agus gur the artist that.is big at.her the spider and that.is mhór a cuid damhan alla, Louise Bourgeois, fuair sí bás big her share of.spiders L. B. got she death ar na mallaibh.

recently

An artist who valued the spiders greatly and whose spiders were plenty, Louise Bourgeois, died recently.

(The first sentence of a newspaper article, http://www.beo.ie)

IV. Existentials with $a n n^{3}$

(17) 'Bhí lá ann,' a deireadh sé, 'nuair a bhí dhá bhó agam...'

was day there REL said he when was two cow at.me 'There was a day', he said, 'when I had two cows...' (BB: 7)

Irish as a language that uses the cleft construction for thetic utterances is mentioned in Sasse (1987) and Lambrecht \& Polinsky (1997), based on Lewis (1942) and MacCana (1973). However, the topic has not yet

\footnotetext{
${ }^{2}$ The article is an advertisement. An Fáinne Airgid is a new entity here. See also P. Mac Cana's examples which appear as (5) and (6) above.

${ }^{3}$ See McCloskey (2009) and literature cited there for syntactical analysis of existential ann.
} 
received further investigation and we do not have a list of pragmatic functions that can be performed by the cleft in Modern Irish (be they thetic or not). As it has been pointed out above, the very notion of theticity is vague and needs to be specified for each individual language.

The aim of this paper is to outline a set of pragmatic contexts in Modern Irish where the cleft construction is used with no focalisation of a clefted constituent taking place. The issue of whether these uses should be called thetic will not be discussed here. In sections 3 and 4 some trivial prosodic patterns distinguishing focalising and non-focalising uses of cleft will be mentioned and a comparison with the Russian eto-cleft construction will be proposed.

\section{Non-focalising cleft in Irish: Pragmatic functions ${ }^{4}$}

For our analysis we took texts representing different genres and styles: two autobiographical novels (Fr Peadar Ua Laoghaire, Mo Scéal Féin, published 1915, hereinafter MSF, and Myles na gCopaleen, An Béal Bocht, published 1941, hereinafter BB), a detective story (Seán O'Connor, An Guth Istóiche, 2008, hereinafter GI), a textbook on Irish poetry (Caoimhghin Ó Góilidhe, Díolaim Filiochta don Ardteistiméireacht, 1974, hereinafter DF) and fifty newspaper articles. $M S F$ also has an audio version. ${ }^{5}$ The data has not shown any significant differences in cleft uses depending on genre or time of composition: all cleft functions met with in one genre were present in the others as well. ${ }^{6}$

\footnotetext{
${ }^{4}$ The starting point for this classification is 'Guidelines for collecting material on “THETIC UTTERANCES” in European languages' (Sasse 1995: 28-31).

${ }^{5}$ The reading of the text by a native speaker was recorded in 2008 and was accessed at http://www.corkirish.com on 05.12.2011.

${ }^{6}$ We have not performed any statictical comparison due to the insufficient data, but would like to mention one tendency: newpapers use cleft sentences in thetic contexts very rarely and prefer other means, the favourite one being 'artificial topicalisation' [(16) above], sometimes with the predicate repetition. The authors of the analysed novels resort to this strategem too when the subject is a heavy NP, e.g. containing a relative clause (a), or a phrase in brackets (b). a. Sa bhliain d'aois an Tighearna míle ocht gcéad cheithre fichid a deich... in.the year $\quad$ God's 1890 do leath eadrainn an sgéal, go raibh an sagart paróiste a bhí anso spread among.us the story that was the priest of.parish RELwas here $i$ bparóiste Chaisleáin Ua Liathain, go raibh sé ag dul chun bais. in parish C. that was he at go-vN to death In the year 1890, news spread among us that a parish priest that was here in the parish Caisleán Ua Liathain, that he was dying. (MSF, 30-7).
}
b. Thugan t-Athair Séamus (an Canónach anois), thug sé dinnéar breagh gave the Father Seamus the Canon now gave he dinner excellent brothalach dúinn. luxurious to.us
Father Séamus (a Canon now) gave us an excellent luxurious dinner (MSF, 29-25). 
The functions found in our data are the following:

I. Annunciative

(18) Sraith nua faoi fhilí agus faoin bhfiliocht... a bhionn program new about poets and about.the poetry REL is:HAB le cloisteáil gach Céadaoin ag 1.30 p.m. ar RTÉ with listen-VN every Thursday at $1.30 \mathrm{p} . \mathrm{m}$. on RTÉ Raidió na Gaeltachta.

R. n. G.

A new program on poets and poetry is on RTÉ Radió na Gaeltachta each Thursday at 1.30 p.m. (http://www.galwayindependent.com)

II. Text opening

(19) Aighneasa tharla idir anfile ó Éirinn dispute REL happened between thepoet from Ireland agus an t-iascaire ón gCorsaic... and the fisherman from.the Corsica There arose a dispute between a poet from Ireland and a fisherman from Corsica. (DF: 381)

III. Existential (usually introducing a new discourse topic)

(20) Duine anoir ó Chill Mocheallóg a bhíodh sa man from.east from C. M. REL was in.the chathaoir(sic) againn i gcaitheamh na h-aimsire sin. town at.us during the time that A man from Cill Mocheallog in the east was in the town with us during that time. (MSF: 24-6; = (3) above)

IV. Descriptive

(21) Pictiúr leathmhagúil, leathgheanúil atá againn anseode picture half-mocking half-loving REL.isat.us here of sheanbhád canálachá tharraingt go mall ag an old.boat of.canal to.its pull:VN slowly at the seanchapall... old.horse

Here we have a half-mocking, half-loving depiction of an old canal boat being pulled by an old horse... (DF: 388 )

V. Connecting episodes

(22) An scéal céanna a bhí ag Joe. the story same REL was at J.

It was the same story with Joe. (GI: 72) 
(23) A mhalairt de scéal a bhí ag Brian. its reverse of story REL was at B. It was the opposite story with Brian. (GI: 72)

Instances I-V are properly thetic: neither subject nor object are presupposed by the context. There are also utterances whose functions are to a high degree similar to those of thetic sentences, e.g. opening a new episode with a character presented earlier in the text. They often have a form of a cleft construction too, but it is not always the subject that is extracted.

VI. Introducing a new episode (with a given subject)

Ara slí chun uachtar reoite a cheannach a bhí sí. on herway to ice-cream PRT buy-VN REL was she She was on her way to buy an ice-cream. (GI: 39$)^{7}$

Often it is a scene-setting adverb that is clefted in such instances:

(25) $\mathrm{Ba}$ thart ar an am sin a bhog Daid isteach was around on the time this REL moved Dad inside sa seomra beag codlata a bhíodh agamsa roimh in.the room small sleeping REL was at.me before dhul le sagartóireacht dom... go: $\mathrm{VN}$ to priesthood by.me It was around that time that Dad moved to a small sleeping room that used to be mine before I became a priest. (GI: 42)

VII. Explanatory

(26) Oíche Dé Máirt is fearr chun glaoch orm, mar evening of.Monday is the.best to call on.mebecause is ag imirt beiriste sa bhunscoil a bhionn Mam. is at play-VN bridge in.the primary.school REL is:HAB Mum Is ó Bhré atáim ag glaoch ort anocht. is from B. REL-I.am at call-VN on.you tonight Monday evening is the best time to call me, because Mom is playing bridge in the primary school. It's from Bré that I am calling you now. (GI: 36)

VIII. Introducing an unexpected event

(27) Is orm-sa a bhí an iongnadh nuaira glaodhadh is on.me REL was the surprise when was.called m'ainim ar dtúis.

my.name on beginning I was amazed when my name was called out the first. (MSF, 14-12)

\footnotetext{
${ }^{7}$ Here the author begins an account of what the character saw under hypnosis.
} 
This list may be not exhaustive and further research on the basis of a larger corpus is needed.

\section{Thetic/categorial ambiguity of the cleft sentences. Some basic prosodic patterns}

In sentences with extracted subjects, ambiguity often arises: an utterance can be interpreted either as thetic or as subject-focal, depending on the context.

(28) Tadhg ó h-Arrachtáin a bhí mar aturnae ag cosaint

T. REL was as solicitor at defend-VN

an Bhrianaigh.

of.the Brianach

The solicitor defending the Brianach was Tadhg ó h-Arrachtáin.

(MSF, 29-13)

Categorial reading: ${ }^{8}$

Presupposition: The Brianach had a solicitor X.

Assertion: $\mathrm{X}$ was Tadhg Ó h-Arrachtáin.

(Possible context: answering the question 'Who was protecting the Brianach?')

Thetic reading:

Presupposition: -

Assertion: The solicitor defending the Brianach was Tadhg Ó hArrachtáin.

(Possible context: answering the question 'Why did the Brianach win the process?')

Why are theticity and focalisation of a subject marked in the same way? According to Lambrecht \& Polinsky (1997), thetic marking must involve detopicalisation of nominal constituents. In European languages, the subject is topical and the predicate is focal by default, thus, it is the subject that should be detopicalised. That can be achieved by following one of the two ways: 1) 'formal properties which are conventionally associated with TOPIC arguments can be cancelled' or 2) the subject 'can be coded with formal features which are conventionally associated with FOCUS arguments' (Lambrecht \& Polinsky 1997: 192, emphasis original). The cleft is a way to make a subject focal, and thus it can ascribe thetic meaning to the sentence. (The same principle is used in other

\footnotetext{
${ }^{8}$ We use the model of description from Lambrecht 2000.
} 
languages, which assign to thetic subjects grammatical features of objects, e.g. by incorporation.)

However, thetic sentences and sentences with a focalised constituent are not homophones. In thetic utterances, both clauses are accentuated and the rate of speech does not change significantly during the utterance. In cleft sentences with a focalised constituent, a post-focal clause is usually unaccented, has a lower intensity and a faster rate of speech (compare a thetic cleft in Figure 1 with a focalising cleft in Figure 2).

(29) Is minic a tháinig glaodhach ola sa n-oídhche

is often REL came call of.oil-VN in.the night

chúgham ó Bheinn na Leacht.

to.me from B.

Often a call for anointment came to me at night from Beann na Leacht (MSF, 17-1).

Fig. 1

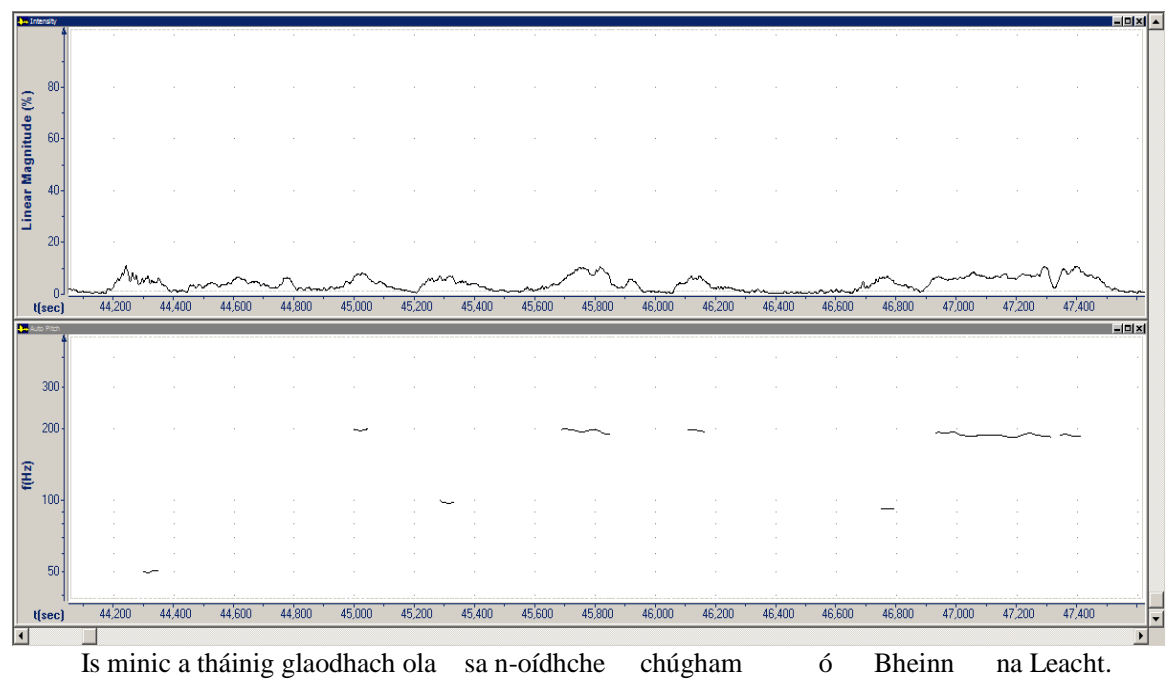

(30) Bhí Cormac agcaint leis na fearaibh.

was C. at talk-VN with the men

As Gaeluinn a bhiodar agcaint.

in Irish REL they.were at talk- VN

Cormac was speaking with the men. It is Irish that they were speaking (MSF, 7-6). 
Fig. 2

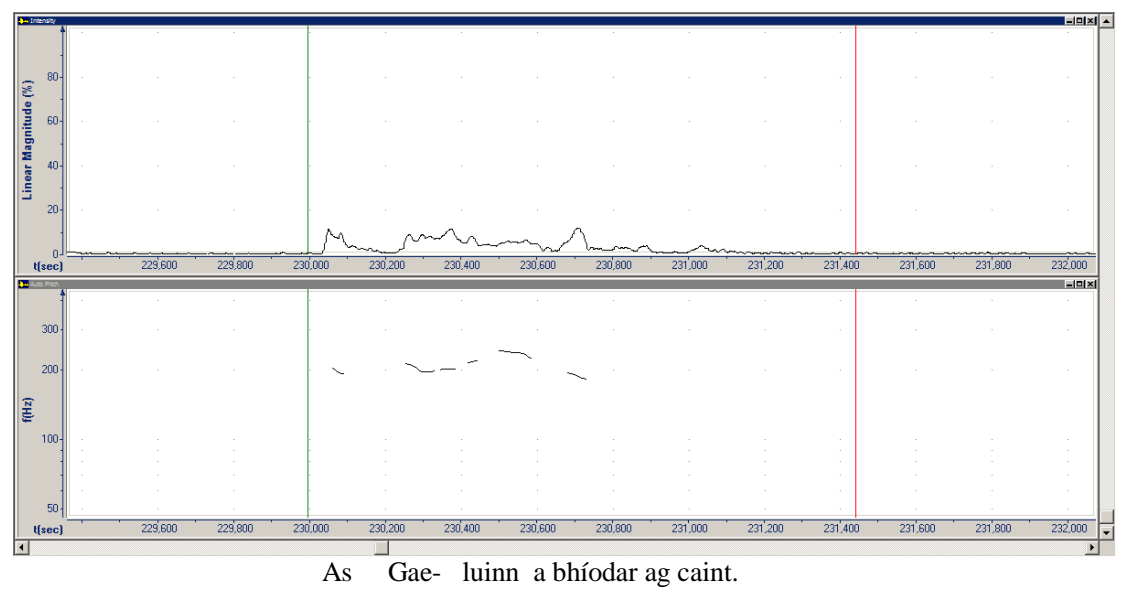

\section{The Russian eto-cleft in comparison with the Irish cleft:}

\section{Conclusion.}

Russian lacks a canonical cleft construction. The so-called eto-cleft, with a deictic particle eto on the left and the remainder being grammatically the same to a categorial sentence, takes some of the other languages' cleft's functions. The eto-cleft has two meanings - focalising a constituent and forming a thetic sentence, illustrated by (31) and (32) resp.

(31) Kto razbilokno? - Eto Pet'a razbil okno.

who broke window PRT P. broke window

Who broke the window? - It is Pet'a who broke the window

(Kimmelman 2007: 1)

Fig. 3

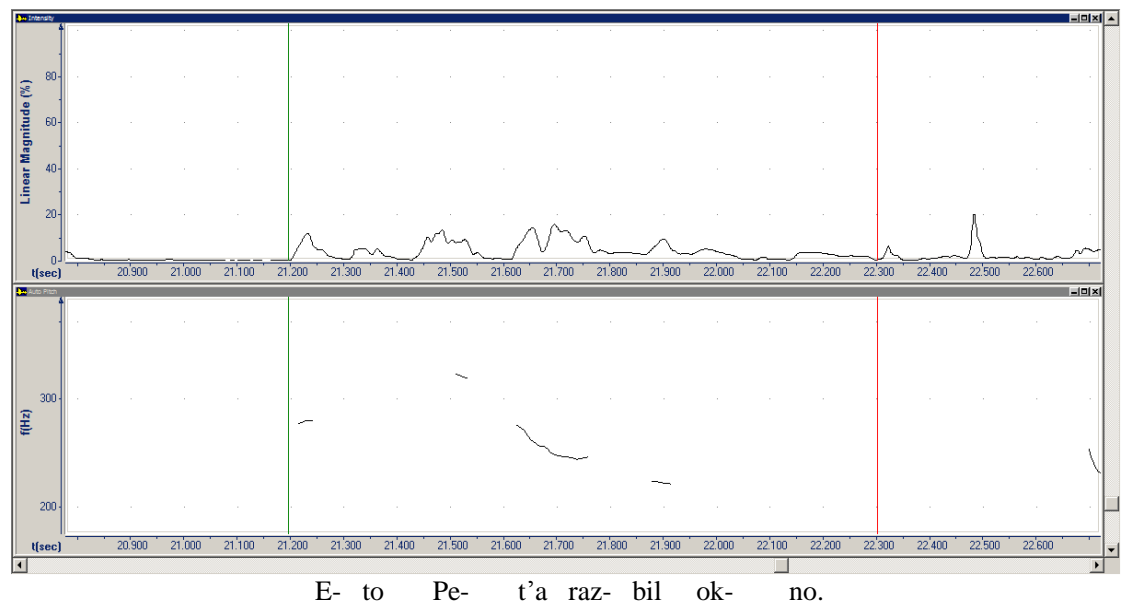


Postfocal material (razbil okno) is unstressed, has a lower intensity, and a more prominent vowel reduction. ${ }^{9}$

Chto $\quad z a$ shum? - Eto Pet'a razbil okno.

what.kind of noise PRT P. broke window

Where does this noise come from? - Pet'a has broken the window.

(Kimmelman 2007: 1)

Fig. 4

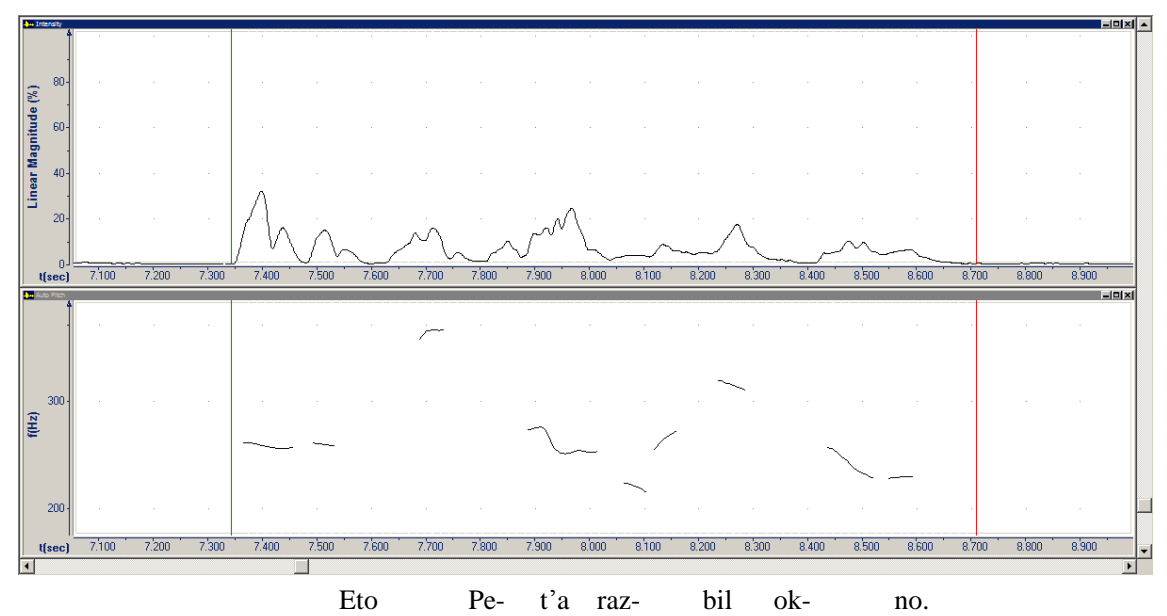

Those two functions of eto-cleft are generally regarded as two separate constructions having different syntactic structures and even different etoparticles (see Kimmelmann 2006, 2007 and literature cited there). However, we may propose that the existence of a typological parallel in Irish enables us to view it as a case of pragmatic homonymy. The parallel is reinforced by the fact that the eto-cleft also distinguishes the two pragmatic meanings prosodically.

Institute of Linguistics, Moscow

${ }^{9}$ See also Kodzasov 1996 on vowel reduction in topics in Russian. 


\section{Abbreviations}

CONT contrastive

HAB habitual aspect

PRT particle

REL relative particle

VOC vocative particle

VN verbal noun

\section{Sources}

http://www.beo.ie (accessed 05.12.2011)

http://www.gaelport.com (accessed 05.12.2011)

http://www.galwayindependent.com (accessed 05.12.2011)

BB: Na gCopaleen, M. , 1992, An Béal Bocht, Cork.

DF: Ó Góilidhe, C., 1974, Díolaim filiochta don Ardteistiméireacht, BÁC.

GI: O’Connor, S. , 2008, An guth istóiche, BÁC.

MSF: Ua Laoghaire, P., 1915, Mo sgéal féin, BÁC. Cited according to http://www.corkirish.com/wordpress/archives/category/mo-sgeal-fein (accessed 05.12.2011) with reference to chapter and paragraph number; audiofiles: http://www.corkirish.com (accessed 05.12.2011).

\section{References}

Graiméar 1999: Graiméar Gaeilge na mBráithre Críostaí, Baile Átha Cliath.

Kimmelman, V. I., 2006, 'Eto-Cleft Constructions in Russian, Forming Thetic Sentences: Syntax, Semantics, Accents (Overview)' (In Russian: Киммельман, В. И., 2006, Вылделительные конструкции с «это» в русском языке, оформляюшие тетические предложения: синтаксис, семантика, акиенты (обзор).) Unpublished thesis.

Kimmelmann, V., 2007, 'On the Interpretation of Eto in the So-called Eto-clefts' (paper presented at FDSL-7, 30 November - 2 December 2007).

Kodzasov, S. V., 1996, 'Laws of Phrasal Accentuation' (In Russian: Кодзасов, С. В., 1996, 'Законы фразовой акцентуации', Николаева, Т. М., ред., Просодический строй русской речи. Москва).

Kuroda, S.-Y., 1972, 'The Categorial and the Thetic Judgment. Evidence from Japanese Syntax', Foundations of Language 9, 153-85.

Lambrecht, K. \& Polinsky, M., 1997, 'Typological Variation in Sentence Focus Constructions', CLS 33. Papers from the Panels on Linguistic Ideologies in Contact, 189-206.

Lambrecht, K. P., 2001, 'A Framework for the Analysis of Cleft Constructions', Linguistics 39.3, 463-516. 
Lewis, H., 1942, 'The Sentence in Welsh', Proceedings of the British Academy 28, 259-80.

Mac Cana, P., 1973, 'On Celtic Word Order and the Welsh 'Abnormal' Sentence', Ériu 24, 90-120.

Mathesius, V., 1983 [1929], 'Functional Linguistics', in: Vachek, J., ed., Praguiana, Amsterdam: John Benjamins, 121-42.

McCloskey, J., 2009, 'Irish Existentials' (handout presented at the FACL conference, 23-9 March 2009).

Sasse, H. J., 1987, 'The Thetic/Categorial Distinction Revisited', Linguistics 25, 511-80.

Sasse, H. J., 1995, "Theticity" and VS Order: a Case Study', Sprachtypol. Univ. Forsh. (STUF) 48, 3-31. 